\title{
Mídia radiofônica: do local ao global
}

\author{
Libny Silva Freire*
}

LIMA, Maria Érica de Oliveira. Mídia regional: indústria, mercado e cultura. Natal: EDUFRN, 2010. 256 p.

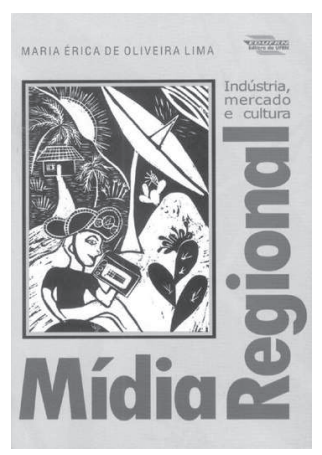

$\mathrm{O}$ livro da Profa. Dra. Maria Érica de Oliveira Lima, traz um estudo de caso sobre a rede cearense Somzoom Sat $\square$ rádio operada via satélite $\square$ a partir do seguinte questionamento: Qual a contribuição da rede na difusão da indústria cultural regional?

Nascido da tese do doutorado em Comunicação Social sob a orientação de Anamaria Fadul, a publicação investiga e registra o surgimento da Somzoom Sat, incluindo sua programação, emissoras de rede e afiliadas, além de trabalhar com os conceitos que levam ao entendimento desse fenômeno comunicacional, como as novas tecnologias e a globalização.

Em 1990 - também ano de criação da Somzoom Sat 『 com o advento da internet, a indústria fonográfica passou por novas configurações, a fim de se manter como mediadora entre artista e público. Novos dispositivos foram adotados e mídias foram surgindo ou se readaptando para manter sua hegemonia na produção e difusão musical.

A mídia radiofônica, como integrante da indústria fonográfica, se utiliza dos mesmos dispositivos de que lança mão a indústria cultural. A lógica do mercado transforma a música em produto, pronto para o consumo.

* Mestranda do Programa de Pós-Graduação em Estudos da Mídia - PpgEM da Universidade Federal do Rio Grande do Norte (UFRN). Atua na linha de produção de sentido e faz parte dos grupos de pesquisas PRAGMA e Comídia. Natal, RN, Brasil. 
No caso da Somzoom Sat, temos o produto forró eletrônico, gênero musical nascido do forró tradicional nordestino. O termo "eletrônico" foi dado por causa do uso de instrumentos eletrônicos, como guitarra e bateria, diferindo do trio - sanfona, zabumba e triângulo - característicos dos demais estilos de forró.

Com a tecnologia vieram o MP3 e downloads gratuitos, alterando as relações da indústria fonográfica com a sociedade, e, portanto, os consumidores de seu produto música. A partir desse cenário, o forró eletrônico se apresenta como uma alternativa para essa indústria manter seu público, ajudando no surgimento de emissoras de rádio, com caráter cultural, gerando identificação, promovendo além da regionalização, a nacionalização do ritmo nordestino e sua possível internacionalização.

A Somzoom Sat envolve um conjunto de outras empresas no mesmo segmento, indo do rádio via satélite ao entretenimento, como disco, selo fonográfico, bandas de forró e casas de shows e estúdio de gravação, tendo, porém como segmento de maior sucesso as bandas de forró. O livro apresenta as técnicas utilizadas por essas empresas no combate à pirataria, intensificada a partir da chegada do CD (Compact Disc), com os quais cópias são vendidas a um custo menor. Uma das estratégias de combate, observada no NorteNordeste, é a produção e venda do CD pelo mesmo indivíduo, ou seja, ele é proprietário da fábrica e da loja que o revende. Há o exemplo da $\mathrm{CD}^{+}$, marca registrada da Nordeste Digital Line S/A, com sede no município de Caucaia (CE) e filial na Zona Franca de Manaus (AM), umas das mais modernas indústrias do Brasil, é responsável por descentralizar a fabricação dos CDs, anteriormente concentrada em cidades como São Paulo e Belo Horizonte. A empresa atua ainda nos setores de informática, com provedores de acesso à internet.

O forró eletrônico é o que mais se utiliza dos dispositivos midiáticos para sua difusão. Além da musicalidade, é ainda um espetáculo visual, os shows possuem alta tecnologia, que vão desde telões e gelo seco a dançarinas fantasiadas. É um subgênero do forró que surgiu devido a esse novo território da indústria fonográfica, no qual variadas transformações ocorreram, principalmente no que diz respeito à produção e distribuição da música. Hoje, algumas 
etapas do processo de difusão estão nas mãos dos artistas e agentes e não mais apenas de uma empresa, que detinha o processo de gerenciamento do produto, do marketing e da difusão. A partir daí, é possível perceber o surgimento de novos estilos musicais, uma produção mais independente de gravadoras, os videoclipes são acessados na internet e o acesso não é mais restrito ao que a MTV (Music Television) agenda, artistas locais produzindo sem necessitar sair de suas regiões. Apesar da indústria fonográfica se caracterizar por grandes conglomerados, essas mudanças deram espaço ao processo de terceirização, onde a produção fragmentada abre espaço para as pequenas empresas. Essa nova configuração de mercado atinge demais setores como cinema, televisão e publicidade.

Nos seis capítulos que integram o livro, a pesquisadora, por meio de uma leitura atual do cenário, discorre sobre esse fenômeno cultural, disseminado pela rádio via satélite. A história do rádio no Brasil e no Ceará, assim como a banda Mastruz com Leite - pioneira no gênero forró eletrônico - e logo copiada pelas demais bandas. A obra apresenta as origens do forró, citando Luiz Gonzaga - considerado o Rei do Baião e o apontando como um dos responsáveis pela divulgação da música nordestina pelo Brasil e o surgimento de novos artistas.

É possível encontrar no livro também diversos quadros - por ser uma pesquisa qualitativa e quantitativa - nos quais são mapeados as emissoras de rádio nacionais, enumerados todos os programas veiculados pela Somzoom Sat, incluindo horário e descrição. Há ainda um quadro com os números da indústria do forró, como tiragens de discos, empregos diretos, público em média por noite e os custos para se montar uma banda.

Numa sociedade da informação - na qual estão aliadas tecnologia, sociedade e informação - ignorar a internet é tarefa impossível, portanto, a pesquisadora se mune de dados coletados no site de relacionamentos Orkut, na comunidade Comunidade Rede Somzoom Sat. Os internautas e participantes, de diversas regiões brasileiras opinam travam discussões, mediadas pela autora, sobre o grupo cearense e sua atuação no mercado.

Amparada por estudiosos da área, a obra lança novos olhares sobre a cultura na sociedade e em como é formada a identidade 
regional, quais mecanismos são utilizados nesse novo panorama da indústria fonográfica local, visando o nacional e, por conseguinte o global, também se reflete como as ferramentas da globalização são usadas na regionalização.

Os produtos da indústria cultural estão imbuídos de subjetividade, numa sociedade repleta de manifestações culturais diversas, tais como religião, música, crenças e valores, essa indústria produz os mais diferentes sentidos nos indivíduos.

O livro põe em discussão a existência desse grupo empresarial no Nordeste - rede Somzoom Sat - que alia mídia radiofônica e cultura, a fim de divulgar sua produção, por meio da tecnologia e elementos culturais identitários, e tudo isso, fora do eixo RioSão Paulo, sabidamente hegemônico, quando falamos também em indústria fonográfica.

É, portanto, leitura recomendada aos pesquisadores da Comunicação, música e fenômenos culturais e todos que se interessam pelas transformações pelas quais passa a mídia brasileira, como funciona, se expande e se estabelece tanto em âmbito regional, quanto nacional. 